\title{
European federal criminal law: What can Europe learn from the US system of federal criminal law to solve its sovereign debt crisis?
}

\author{
Carlos Gómez-Jara ${ }^{1}$
}

The lack of a strong law enforcement authority in the EU with competence in criminal matters that monitors how European funds are applied can be considered one of the main reasons behind the disastrous spending of EU member states. This paper contends that EU funds are to be treated as "federal" funds, and the mismanagement of those has to be prosecuted and punished by the EU itself. On top of longstanding arguments for the legitimacy of EU institutions to enforce criminal sanctions in order to protect its own funds, an additional rationale has become apparent in the outcome of the sovereign debt crisis. As many law and finance studies have shown, there is a close relationship between law enforcement capacity and investors' confidence. Therefore, to restore investors' confidence in the Eurozone's debt, a strong EU law enforcement authority in criminal matters is needed. The parallelism with the US approach is deserved: mismanagement of federal funds is a federal crime prosecuted at federal level. Though not a federal State, the EU has in this area the same problems as if it were. The injection of billions of euros through the bailout programs makes the situation ever more pressing. If the EU is able to provide a uniform system of enforcement at the EU level i.e., federal, not national, level, in matters concerning criminal misconduct affecting EU financial interests, investors will more likely regain the confidence lost in European sovereign debt.

Keywords: component; European criminal law; sovereign debt crisis; federal system; law enforcement, law and finance, investors' confidence

\section{Introduction}

In a recent speech, the Justice Commissioner, Viviane Reading, clearly stated "A federal budget needs federal protection". In her view the EU budget "is a federal budget. If we don't protect it, nobody else will do it for us", Probably, no other EU official has uttered such an obvious relationship between the EU budget and the enactment of a European federal criminal law. ${ }^{3}$ This speech was given the same day that the Commission laid out its proposal for the establishment of the European Public Prosecutor Office ${ }^{4}$.Although "federalism" - not to mention "Federal" crim-

\footnotetext{
${ }^{1}$ Associate Professor of Criminal Law. Universidad Autónoma de Madrid (Spain). Contact: carlos.gomezjara@uam.es

2 Speech $13 / 644$

${ }^{3}$ See Carlos Gómez-Jara Díez, Models for a System of European Criminal Law: Unification vs. Harmonization, 1 New Journal of European Criminal Law 384(2010) proposing a European federal criminal law limited to the protection of EU financial interests and a harmonized criminal law in matters concerning serious cross-border criminality.

${ }^{4}$ COM(2013)534final.
} 
inal law - is considered to be an "F-word" in the EU ${ }^{5}$, the current EU situation demands an innovative approach. This might imply stepping out of what is "politically correct" and acknowledging that, although not a federal state, the EU has the same problems as if it were.

For decades, countries in Europe and the EU itself have played with the idea of developing a system of European criminal law ${ }^{6}$. Interest in this matter waxed and waned, but ultimately neither disappeared nor was consolidated. No doubt the catalyser to finally prompt the decision one way or the other will come in the form of a dramatic event. This paper contends that this type of inflection-point event has arrived with the 2010 sovereign debt crisis and its progeny. The present situation is basically as dramatic as it can get, with entire nations in the brink of default and their populations having to deal with major trims to social welfare. But, what has criminal law, or more specifically federal criminal law, got to do with it?

As will be described in more detail below, the EU has paid increasing attention to the need of protecting taxpayers' money through criminal law. The mechanisms in place have not been up to the task so far and the need for reform has become increasingly acute. The proposals target fundamentally national legislation to the extent that they provide diverse levels of protection. Though welcomed, there seems to be an underlying structural deficit that will remain unaddressed if these parched reforms are not accompanied by a new institutional framework. Conspicuously, the enforcement angle will be reinforced shortly (or at least that seems to be the EU's intention) by creating the European Prosecutor's Office already foreseen in Art. 86 TFEU, and establishing a special court in the ECJ by means of Art. 257 TFEU.

This new approach sets the EU on the path of enacting and enforcing what could be better described as a European federal criminal law: EU criminal provisions enforced by EU criminal enforcement institutions. This short paper will note the recently adopted steps made in pursuit of this goal. To be sure, no attempt will be made at providing an overview of past and present positions regarding the legitimacy and enforcement deficits of EU criminal law, but rather it will solely attest to the willingness of the EU to overcome the present situation while noting the advantages of such an approach to appease the financial market's pressure. Will this wellintended endeavour suffice? Much of the future of the EU probably rests upon a successful completion of the task.

The history of the EU itself can be probably explained as subsequent reactions to a Europe-threatening crisis. It can hardly be questioned that the foundational EEC Treaty was closely linked to the crisis unravelled by the dramatic experience of World War II. At the time, a European Union - or, as Churchill ${ }^{7}$ and Eisenhower ${ }^{8}-$

\footnotetext{
${ }^{5}$ Philippe C. Schmitter, Democracy in Europe and Europe's democratization, 14 Journal of Democracy 74 (2003).

${ }^{6}$ For a general overview see Andre Klip, European Criminal Law: An Integrative Approach. 2nd Ed. (2012); Helmut Satzger, International and European Criminal Law (2012); Ester Herlin-Karnell, The Constitutional Dimension of European Criminal Law (2012); Valsamis Mitsilegas, EU Criminal Law (2009). In German, see Bernd Hecker, Europäisches Strafrecht (2nd ed. 2008). Europäisches Strafrecht post-Lissabon (Kai Ambos ed., 2012); Europäisches Strafrecht (Sieber, Brüner, Satzger \& v. Heintschel-Heinegg (eds,) 2012).
} 
worded it: a "United States of Europe" - seemed the only way to avert a future crisis of that calibre. Now, the current crisis that has lead to what has been termed maybe too dramatically - as World War III (the Currency War ${ }^{9}$ ) seems to pave the way for a similar solution: more Europe (not less) is the answer. True, some critics of the EU are proposing disintegration as a better solution that unification ${ }^{10}$. But the economic rationale (not to mention political and cultural European achievements) indicates otherwise.

Servatiadistantia the US experience in the late 18th Century should shed some light. After the war for independence was over, the remaining states were heavily indebted and the lack of a strong national central government could disintegrate the fragile union $^{11}$. The states (not the Union) collectively owed about 25 Million USD. Hamilton suggested that the federal government assume the states' war debts. He felt that this consolidation of state and federal debt would give investors who held that debt a reason to support the federal government ${ }^{12}$. The solution was to create the First National Bank of the United States that would be funded with 10 Million USD through an IPO that was primarily directed at private investors.

Indeed, the EU already has a European Central Bank in place, (though it is funded by the EU Member States) ${ }^{13}$ and the Euro-bond solution ${ }^{14}$ issued by the ECB itself does not seem to be a clear option right now. But the crux of the matter from a criminal law point of view is the accompanying legislation that was enacted in the US pursuant to the solution implemented. In $1798^{15}$, the US Congress passed legislation designed to protect the financial interests of the Union. If the EU is to take similar measures

\footnotetext{
${ }^{7}$ Winston Churchill, Speech at the University of Zurich, 19th September, 1946. Available at: http://www. churchill-society-london.org.uk/astonish.html

${ }^{8}$ Dwight David Eisenhower, Speech at the English Speaking Union Dinner at Grosvenor House, London, 3rd July, 1951. Available at: http://www.eisenhowermemorial.org/stories/english-speaking-union-speech.htm

${ }^{9}$ James Richard, Currency Wars. The Making of the Next Global Crisis, 2011.

${ }^{10}$ This includes the "more modest Europe" solution committing itself to "unity in diversity" proposed by Christian Joerges, Europe's Economic Constitution in Crisis. Zentra Workings Papers in Transnational Studies, No. 06/2012. Although acknowledgingt hat "Europe is in bad shape" (at 3) he proposes a "conflicts law" based on requiring EU Member States to "take their neighbors concerns seriously" and to "structure cooperative solutions to problems in specific areas" (at 25). This approach, again, does not address the underlying problem and will probably not restore theconfidence of thefinancial markets. A strong determination towards unification seems the onlyway to clearly signal that the EU is a "safe bet" for investors.

${ }^{11}$ The First Bank of the United States. A Chapter in the History of Central Banking.Federal Reserve Bank of Philadelphia. June 2009 at 1. the new nation's leaders had their work cut out for them: re-establishing commerce and industry, repaying war debt, restoring thevalue of the currency, and lowering inflation.

${ }^{12}$ It goes without saying that many prominent figures of the American democracy were against Hamilton's solution. Thomas Jefferson, for one, was afraid that a fiscal union would create a financia lmonopoly that would undermine state banks, and that the solution was unconstitutional. James Madison was also against it noting that it was an affront to states' rights and would make the states too subservient to the new federal government, The First Bank of the United States. A Chapter in the History of Central Banking.Federal Reserve Bank of Philadelphia. June 2009 at 3].

${ }^{13}$ See the interesting analysis of Paul De Grauwe, The European Central Bank: Lender of Last Resort in the Government Bond Markets?,CESIFO WORKING PAPER NO. 3569, 2011.

${ }^{14}$ See Kenneth Matziorinis, Is the 'Euro Bond' the Answer to the Euro Sovereign Debt Crisis? Wha tOutcome can Investors Expect out of Europe?, December 2011. Available at: http://ssrn.com/abstract=1999518 suggestingt hat pooling fiscal risks, creatingan EU Treasury and is suing jointly-backed euro bonds is an optimal solution and the inevitable conclusion of the economic integration project in Europe.

${ }^{15}$ Act of June 27, 1798, 1 Stat. 573. Chap. LXI.-An Act to punish frauds committed on the Bank of theUnitedStates. Thefirst federal criminal statute was signed into law on April 30, 1790.
} 
regarding a fiscal Union, with a clear interest in preserving Europe's financial health, then it seems equally clear that criminal legislation should be enacted to protect already existing EU financial interests and, to a greater extent, new emerging interests.

\section{USA v. Europe: Different approaches to the same problem?}

From an economic perspective, the US and the EU seem to have adopted different approaches to the 21st Century financial crisis. The US has lowered interest in an unprecedented manoeuvre, fuelling liquidity into the system through massive injections of capital i.e., QE programs, and a strong determination to increase debt as necessary to avoid recession. In sharp contrast, the EU has been cautiously tackling its reserves, injecting liquidity as a last resort. Only after major struggles and accepting draconian budgetary restrictions to prevent inflation have EU member states been able to tap into the all too needed EU funds ${ }^{16}$. The opposite goals seem to be at stake: avoiding recession vs. avoiding inflation.

The reasons for this divergent approach are manifold. Though maybe naïve, historic memory might be playing an important role. The American collective reminiscence of the Great Depression could still be very present ${ }^{17}$. The German hyperinflation in the Weimar Republic may also have an impact on the approach the EU dominant nation is taking towards the crisis $^{18}$. But notwithstanding the importance of these considerations, a significant difference appears whenever a comparison is raised between the US and the EU: the latter is not a federal State. Even if the EU (not specific Member States) wanted to pursue a similar policy, its structure and powers show important limitations that prevent authentic EU action ${ }^{19}$.

The EU has become aware of this fundamental deficit, and recent proposals (including Treaty Reform) are aimed at surmounting those limitations. As will be outlined below, those proposals include (and must include) mechanisms to enhance protection of EU financial interests from a legal point of view. Normally, criminal law sanctions and their enforcement have been left out of the picture as a result of States' sovereignty concerns ${ }^{20}$. But given the current state of affairs, with billions of

\footnotetext{
${ }^{16}$ For a general consideration of the relationships between sovereign debt crisis and bailouts see Francisco Roch and Harald Uhlig, The Dynamics of Sovereign Debt Crises and Bailouts, available at: ec.europa.eu/economy_finance/events/.../day2-paper1_en.pdf.

${ }^{17}$ It has often been pointed out that the deep knowledge of the Great Depression by Ben Bernanke, Chairman of the Federal Reserve during the financial crisis, has impacted decisively on the American approach to the 2008 crisis. See Laurence Ball, Ben Bernanke and the Zero Bound, NBER Working Paper No. w17836 (February 2012). See also the reflections of Ben Bernanke himself in Ben Bernanke \& Harold James, The Gold Standard, Deflation, and Financial Crisis in the Great Depression: An International Comparison, in Financial Markets and Financial Crises (R. Glenn Hubbard, ed.), at 33-68.

${ }^{18}$ See Theo Balderston, Economics and Politics in the Weimar Republic, 2002.

${ }^{19}$ The strong federal power that now permeates US economic and legal policy provides the necessary tools to act promptly against economic downturns and their underlying causes. Not only does it enable rapid massive capital injections that do not burden state and local budgets (but the federal budget); it also entitles the federal government to immediate action with an array of enforcement possibilities yet unknown to the EU structure. If the EU is willing to achieve such immediate action enforcement capabilities, it must acquire a similar structure.

${ }^{20}$ For a classic account of the critics see Peter Alexis Albrecht \& Stephan Braum, Deficiencies in the development of European Criminal Law, European Law Journal 5 (1999), 293-310.
} 
Euros pouring from EU facilities to ailing Member States, sovereignty warnings have become less audible and liquidity needs more palatable. It would be far from reasonable to trust adequate management of bailout funds to the same countries that mismanaged EU funds in the first place.

In a way, it has become increasingly clear that if the EU is to solve the sovereign debt problem once and for all, a movement towards unification is needed. As noted below, this trend is quickly advancing in the banking system, to the extent that on 13th December, 2012, the Council of the EU agreed on establishing the ECB as a European Supervision Authority ${ }^{21}$. Yet, the point to be made is that something similar is needed at the (criminal) enforcement level. Notwithstanding the timid attempts perpetrated so far, a more consistent and determined step is to be taken in the face of a rapidly changing financial environment. To the same extent that sovereignty is being transferred to the EU for purposes of advancing a unified banking supervision authority ${ }^{22}$, Member States should enable sovereignty transfer in matters concerning the protection of the EU financial interests against criminal misconduct. Again, some work is already in progress and will be outlined in the remainder of this paper. But if "a good crisis should never to go waste" 23 , then the EU should seize the opportunity of gaining enforcement power in the area of criminal law - restricted, though, to the protection of EU financial interests.

\section{The financial markets' pressure}

If anything, the financial crisis has made it clear that markets outpace politics. The liquidity crisis affecting financial institutions has turned into a credit crunch affecting the ability of entire nations to fund their national budgets. Politicians throughout the EU have been constantly concerned with the risk premium of their sovereign debt. And while markets have relentlessly pounded their sovereign debt, the political action of the EU has remained dormant. Solidarity of wealthier nations of the EU has been the recurrent theme in and outside the political scenario of less favoured states; but the need for decisive action by the EU itself has been delayed over time.

It is not surprising, therefore, that the spike in the borrowing costs of such states has forced once proud EU nations to kneel down and request a bailout. While the spread of the contagious financial disease ${ }^{24}$ has triggered bailout requests by

\footnotetext{
21 17739/12. PRESSE 528

${ }^{22}$ The recent Symposium The Sovereign Debt Crisis: Towards Fiscal Union in Europe?, held on Thursday 7th June, 2012, clearly signaled the path to overcome the current situation.

${ }^{23}$ This well-known citation is used by John C. Coffee, The Political Economy of Dodd-Frank: Why Financial Reform Tends to be Frustrated and Systemic Risk Perpetuated, Cornell Law Review 2012. Available at: http:// papers.ssrn.com/sol3/papers.cfm?abstract_id=1982128 to justify that "that only after a catastrophic market collapse, can legislators and regulators overcome the resistance of the financial community and adopt comprehensive "reform" legislation." In a similar fashion JurgenHabermas, The Crisis of the European Union. A response. 2012 sees "crisis as opportunity" to deepen Europe's democratic credentials.

${ }^{24}$ See Sebastian Missio and Sebastian Watzka, Financial Contagion and the European Debt Crisis, CESIFO working paper no. 3554, August 2011.
} 
modern western nations like falling dominoes ${ }^{25}$, the patchwork solutions have made clear the necessity of a long-term solution that comports a new institutional design in the EU. The European Financial Stability Facility [hereinafter: EFSF] ${ }^{26}$, the European Financial Stabilisation Mechanism [EFSM] or the recent European Stability Mechanism [ESM] are clear examples of the attempts of the EU to alleviate the pressure of the financial markets with an eye on a more permanent solution $^{27}$. The recent decision in December 2012 to establish by 2014 the ECB as a European Banking Supervision Authority for the oversight of credit institutions confirms this trend ${ }^{28}$.

One circumstance, though, seems evident in the quid pro quo trade between bailout countries and the EU. In order to have access to the much-desired funds, they have to give up sovereignty. National budgets have been trimmed, control over financial decisions has been handed over to the EU and certain EU economic goals have become national policy. Moreover, even blatant signs of sovereignty such as national elections have been put aside temporarily. The cases of Greece and Italy show that, when push comes to shove, an EU friendly politician must govern the country. To put it otherwise: the political will of the EU has temporarily replaced the political will of EU citizens that were reluctant to accept major reductions of the welfare state.

In the wake of such sovereignty transfers, another equally important step seems to be in process. As will be outlined below, the EU is slowly becoming conscious of the importance of a traditional expression of state sovereignty: criminal law. This is the reason why this paper contends that the question of developing an effective European criminal law has become more pressing since the sovereign debt crisis of $2010^{29}$. Moreover, it contends that the current state of events confer on the EU the necessary legitimacy to enact criminal legislation in order to protect the European taxpayers' and foreign investors' money that is already being poured into some Member States. The main reason for this assertion is that a long-term solution to the threat to the EU - through the Eurozone - posed by the financial markets must include a criminal oversight mechanism enforced by the EU itself. The injection of European funds into ailing countries can only be guaranteed if there is proper supervision of the final destination of those funds.

\footnotetext{
${ }^{25}$ See Roberto A. De Santis, The Euro Area Sovereign Debt Crisis: Safe haven, Credit Rating Agencies and the Spread of the Fever from Greece, Ireland and Portugal, European Central Bank, Working Paper SeriesNo 1419, February 2012.

${ }^{26}$ See among many Huizinga, Harry \&Horváth, Bálint, Does the European Financial Stability Facility Bail Out Sovereigns or Banks? An Event Study (November 10, 2011).European Banking Center Discussion Paper No. 2011031. Available at SSRN: http://ssrn.com/abstract=1957584.

${ }^{27}$ See the extensive analysis by Rodrigo Olivares-Caminal, The EU Architecture To Avert a Sovereign Debt Crisis, available at: http://www.oecd.org/finance/financialmarkets/49191980.pdf, which was presented at the Symposium on Financial Crisis Management and the Use of Government Guarantees, held at the OECD in Paris on 3rd and 4th October, 2011.

${ }^{28} 17739 / 12$. PRESSE 528

${ }^{29}$ An interesting approach to the origins to the crisis, the political challenges of the EU to solve it and the consequences of the (potential) Greek departure is conducted by Martin Feldstein, The Euro and The European Economic Conditions. National Bureau of Economic Research Working Paper 17617 (2011).
} 
Real criminal enforcement by EU institutions is a "must" if the system is to have a chance of succeeding. To be sure, the mismanagement of European funds has been an ever-recurring theme of recent EU history. The lack of a strong law enforcement authority in the EU with competence in criminal matters that monitors how these funds are applied can be considered one of the main reasons behind the disastrous spending of EU member states. To the same extent that US bailout funds for ailing US companies were closely monitored by the Department of Justice [hereinafter: DOJ] ${ }^{30}$, there is a real need for similar mechanisms in the EU. To put it simply, EU funds should be treated as federal funds, and the mismanagement of those has to be prosecuted and punished by the EU.

In short, the question raised by the financial markets is quite simple: Can investors be confident that their investments in European sovereign debt are secure when enforcement is not? Moreover, can EU taxpayers be certain that their painful effort will be worth it when the EU lacks full enforcement mechanisms to avoid mismanagement of those funds? There is clearly a moral hazard in the fact that EU funds are rescuing ailing nations, but mismanagement of those funds cannot be prosecuted at the EU level. If egregious misconduct affecting EU financial interests should not go unpunished, then full enforcement, including the criminal dimension, at the EU level should be a reasonable demand from EU institutions.

\section{The European approach}

The quick and "typical" EU response to these concerns has been to leave up to Member States the appropriate enforcement of the provisions dealing with the financial interest of the EU. But everything has a limit: and the naiveté of EU institutions, resembling some sort of wilful blindness, cannot go on any longer. There has been too much waste of EU assets ${ }^{31}$ and it would certainly be reassuring for the international financial markets to know that a truly effective EU watchdog will be taking care of the proper allocation of these now extremely highly valued funds. No longer can the EU institutions trust the EU member states to vigorously enforce the proper use of the funds. National institutions have failed time and again to punish the misappropriation of EU funds. The undetected/unreported fraud is

\footnotetext{
30 The Trouble Assets Release Program [TARP] and additional Bailout programs are closely monitored by the DOJ. The amount of money and federal agents deployed for the task of protecting the federal funds has increased since the enactment of the programs in 2008. See just for the FY 2010 the 62.6 Million and the 379 positions (54 agents and 165 attorneys) requested by the DOJ athttp://www.justice.gov/jmd/2010factsheets/pdf/cff-fisc.pdf .

${ }^{31}$ The numbers of fraud affecting the financial interests of the EU are staggering and increasing. Just for the FY 2010, the financial impact of the irregularities detected by control systems in the area of expenditure amounted to EUR 1.8 billion (1.27\% of the allocations), as compared to EUR 1.4 billion (1.13\% of total allocations) in 2009. On the revenue side, the overall financial impact of irregularities was also higher than in 2009: EUR 393 million (1.88\% of total collected Traditional Own Resources, gross) as compared to EUR 357 million (1.84\% of total collected Traditional Own Resources, gross). In short "Overall figures for 2010 indicate that the number of irregularities reported has increased for all sectors" [Report from the Commission to the European Parliament and the Council], Protection of the European Union's financial interests-Fight against fraud-Annual Report 2010 (accessible: http://ec. europa.eu/anti_fraud/reports/commission/2010/EN.pdf). Two additional factors must be taken into account. First, these numbers only reflect reported fraud; the undetected fraud is even greater. Second, the potential increase of EU fraud in light of the amount that will be poured into the ailing EU countries is just breathtaking.
} 
just staggering, and with the upcoming injections that run up to hundreds of billions of Euros, no more leeway can be afforded.

Interestingly enough, the Lisbon treaty contains the necessary provisions to provide the EU with the arsenal it needs. A European Public Prosecutor Office in conjunction with the strengthened agencies of Eurojust and Europol ${ }^{32}$ represent the optimal tool to ensure compliance with the parameters set forth by Brussels ${ }^{33}$. Full protection of the financial interests has become an essential ingredient of the bailout recipe that the EU is trying to work out presently. If the EU refuses to enact legislation for this purpose, it will have missed a great opportunity to advance the protection of one of its vital components. It is not by chance that federal states have always considered it to be a matter of their incumbency to watch over federal monies. The fact that the type of federalism present in the EU is not state federalism, but supranational federalism ${ }^{34}$ should not weigh against the EU. It is matter of design, not of principle.

\section{The American approach}

Against this backdrop, the experience of some federal systems, especially the US, in protecting with criminal sanctions their financial interests, must shed light as to how to implement these provisions. Recognizing the European idiosyncrasy is one thing; neglecting the need for serious EU punishment of misconduct affecting EU funds, is another ${ }^{35}$. Anything other than adopting a similar structure to what the EU already has in terms of protecting fair competition ${ }^{36}$ i. e. the sacrosanct pillar of EU integration, is just begging the question of how much longer the EU can survive without taking a hands-on approach towards governmental misspending. This short piece tries to highlight recent developments that point in this direction and provide additional arguments related to the way in which financial markets operate (including sovereign debt markets).

Without doubt, the American system of federal criminal law is nothing to be imported cum grano salis into Europe. There are too many deficiencies ${ }^{37}$ and too many idiosyncrasies that have to be taken into account. These reflections pretend to

\footnotetext{
${ }^{32}$ For an overview of the proposed structural relationship between Eurojust and the EPPO, see Jorge ÁngelEspina Ramos, Towards a European Public Prosecutor's Office: the Long and Winding Road in Substantive Criminal Law of the European Union (Andre Klip ed., 2011).

${ }^{33}$ For an overview of these agencies and proposed agencies see André Klip, European Criminal Law: An Integrative Approach. 2nd Ed. (2012), 383-414.

${ }^{34}$ On this concept see Armin von Bogdandy, Founding principles, Principles of European Constitutional Law 11 (Bogdandy\& Blast eds., 2009). For an interpretation of the current state of affairs consistent with its tenets see Carlos Gómez-Jara, European Federal Criminal Law (2013).

${ }^{35}$ For an overview of American punishment practices and a comparison with Europe see James Q. Whitman, Harsh Justice: Criminal Punishment and the Widening divide between America and Europe 41-64 (2003).

36 "Competition law is the only area where the European Union currently has direct enforcement powers at its disposal. Competition law has its origins in the internal market from the very beginnings of the European Communities." Andre Klip, European Criminal Law: An Integrative Approach. 2nd Ed. (2012) at 454.

${ }^{37}$ As Sullivan puts it, drawing from other sources, the current US federal criminal "code" is an "incomprehensible," random and incoherent, "duplicative, ambiguous, incomplete, and organizationally nonsensical" mass of federal legislation that carries criminal penalties. Julie E. Sullivan, The Federal Criminal Code is a Disgrace: Obstruction Statutes as a Case Study, 96 J. Crim. L. \& Criminology 643 (2006)
} 
stay at arm's length with the US system, while at the same time try to obtain as much benefit as possible from one of the systems with a greater degree of enforcement experience and political significance. Many times questions about federal criminal law turn out to be questions about federalism. Similarly, the question of EU criminal law is a question of whether there is a EU competence in criminal matters. Resemblances go far beyond this issue: the overreaching enactment of federal criminal law in the US on behalf of the commerce clause ${ }^{38}$ is similar to the proliferation of EU instruments on behalf of the principle of "free movement of goods", as the UE has established that ruling should be considered as "goods" that may freely move within the EU pursuant to the principle of mutual recognition ${ }^{39}$. Interestingly enough, the EU's reluctance to acknowledge its powers in criminal matters has created a sui generis system that, to a certain extent, is more federal than the US system ${ }^{40}$. This is the final "curtain call" for EU institutions and they have to be up to the task of providing an adequate and uniform response to the on-going fraud affecting EU financial interests.

\section{The future ahead}

It will take plenty of political will and determination to adopt such measures. Many Member States will be reluctant to confer such powers to the EU. But the current situation enables the EU to play a quid pro quo with the Member States: if they want the funds, they must agree to the creation of adequate enforcement mechanisms including criminal sanctions when signing the (in)famous Memorandums of Understanding ${ }^{41}$. Great nations have required the outburst of a crisis to consolidate some of their more fundamental structures. The time might have come to finally acknowledge that although not a sovereign state, the EU has the same problems as if it were. And quite frequently similar problems demand similar solutions.

As this paper is being written, the EU is in deep discussion regarding a potential reform of the EU Treaties that would result in a more unified fiscal policy with automatic sanctions for countries that do not comply with the ratios imposed by Brussels $^{42}$. This opportunity of Treaty reform should be used to foster the creation of

\footnotetext{
${ }^{38}$ Norman Abrams, Sara Sun Beale and Susan Riva Klein, Federal Criminal Law and its Enforcement.5th ed (2010).

${ }^{39}$ Wording of the Framework decision establishing the European Arrest Warrant [OJ L190 July 182002 at 1]: "Traditional cooperation relations which have prevailed up till now between Member States should be replaced by a system of free movement of judicial decisions in criminal matters, covering both pre-sentence and final decisions, within an area of freedom, security and justice" http://eur-lex.europa.eu/LexUriServ/LexUriServ.do?uri=CELEX:32002F0584:en:HTML

${ }^{40}$ See Gómez-Jara,European Federal Criminal Law (2013).

${ }^{41}$ Actually, it is clear that the conditions set forth in these MOUs entail a surrender of national sovereignty. See, for instance, the MOU with Greece at http://ec.europa.eu/economy_finance/eu_borrower/mou/2012-03-01-greecemou_en.pdf . A limited cession of sovereignty in criminal matters i. e., limited to cases involving the protection of EU financial interests, would be perfectly consistent with the current trend and Article 325 TFEU. Especially taking into consideration that these are not "genuine" national interests, but interests of a supranational institution: the EU.

${ }^{42}$ For the details see Herman van Rompuy, Towards ab Genuine Economic and Monetary Union, EUCO 120/ 12. 26 June 2012.
} 
the European Prosecutor Office pursuant to Article 86 TFEU ${ }^{43}$ and establish a special court within the European Court of Justice enabled by Article 257 TFEU that, resembling the US system's structure, provides adequate criminal law enforcement. As long as compliance with reforms is left exclusively to the States - leaving the enforcement upon individuals and corporations down to them - the system will be flawed.

\section{Recent developments in the EU approach}

Since the sovereign debt crisis hit the EU with the Greek Episode in May 2010, the EU institutions have developed a greater sense of urgency regarding the implementation of effective measures to protect the EU budget. As we will see though, the final wording of the communications of the EU Commission and EU Council does not address the real problem. Though they clearly acknowledge the problem and even use the correct wording when describing it, they fail time and again to provide the solution that the problem demands. Just as with the snail speed with which EU institutions react to adverse market conditions -triggering strong reprimands from the US and China -, the slow motion approach of the EU towards effective criminal law enforcement of EU funds is anything but reassuring.

\section{Safeguarding taxpayers money?}

A great example of the lack of willingness to act vigorously in this field is the recent communication from the EU Commission to various EU institutions "on the protection of the financial interests of the European Union by criminal law and by administrative investigations. An integrated policy to safeguard taxpayers' money" 44 . While it acknowledges that "The Treaty sets a clear framework for the EU to reinforce its action in the field of criminal law" 45 that "more effective means are also needed to fight criminal activities against the EU Budget" 46 and that there is both "Insufficient protection against criminal misuse of the EU Budget" and "Insufficient legal action to fight criminal activity" 47 , the end result is somewhat mild. This is all the more surprising when it is clear from the text that the EU Commission has a thorough understanding of the necessary mechanisms to articulate the solution: the Commission specifically refers the following four ways to protect EU financial interests under the TFEU:

(i) Measures on procedural judicial cooperation in criminal matters (Article 82).

(ii) Directives containing minimum criminal law rules (Article 83).

\footnotetext{
${ }^{43}$ For a discussion of the legislative process by which the EPPO will be formed, see Andre Klip, European Criminal Law: An Integrative Approach. 2nd Ed. (2012) at 463.

${ }^{44}$ Communication from the Commission to the European Parliament, the Council, the European Economic and Social Committee and the Committee of the Regions. On the protection of the financial interests of the European Union by criminal law and by administrative investigations. An integrated policy to safeguard taxpayers' money.COM (2011) 293 final. Brussels, 26. 5. 2011.

${ }^{45} \operatorname{COM}(2011) 293$ final at 3.

${ }^{46} \operatorname{COM}(2011) 293$ final at 5.

${ }^{47} \operatorname{COM}(2011) 293$ final at 4-5.
} 
(iii) Legislation on fraud affecting the financial interests of the Union (Articles 310(6), 325(4)).

(iv) Article 85 allows granting Eurojust investigative competences and Article 86 allows for the establishment of a European Public Prosecutor Office (EPPO) from Eurojust to combat crimes affecting the financial interests of the Union.

Now, after recognizing the status quo, the need for action and the available resources, it proceeds with the following low key language: "Should criminal law, including further developed definitions of offences and minimum rules on sanctions, be deemed necessary to achieve the legitimate purpose of fighting fraud against the EU budget, certain guiding principles will need to be observed" ${ }^{\prime \prime}$. And then it proceeds to detail procedural safeguards regarding fundamental rights, the approximation of criminal law regimes and the need to reflect on the strengthening of EU Institutions. Given the current state of the situation in the EU, with spiking interests for European sovereign debt, skyrocketing costs to insure it against default i. e. the costs of Credit Default Swaps, and the difficulties with its allocation, (a German government debt auction in November drew some of the weakest demand since the introduction of the euro ${ }^{49}$ ), decisive action must be undertaken.

\section{The so-called anti-fraud strategy}

The immediate response after this communication was, not surprisingly, another communication. The Commission addressed the same institutions on its next "Anti-fraud Strategy" ". The overall objective of the new Commission Anti-Fraud Strategy is to "improve prevention, detection and the conditions for investigations of fraud and to achieve adequate reparation and deterrence, with proportionate and dissuasive sanctions, and respecting the due process, especially by introducing antifraud strategies at Commission Service level respecting and clarifying the different responsibilities of the various stakeholders" ${ }^{, 51}$. This communication states that in 2011, several initiatives will be taken to step up the fight against fraud and corruption affecting EU public money. These initiatives are the following:

The Commission's proposal for amending the legal framework of OLAF aims at increasing the efficiency and speed of OLAF investigations, at strengthening procedural guarantees, at reinforcing OLAF's cooperation with Member States and at improving its governance.

The Communication on the protection of EU financial interests by criminal law and administrative investigations sets out how the Commission intends to safeguard taxpayers' money at EU level against illegal activities, including threats posed by corruption inside and outside the EU institutions. The Communication points to opportunities for improving the criminal law framework and the procedural tools

\footnotetext{
${ }^{48} \operatorname{COM}(2011) 293$ final at 9.

49 Wall Street Journal, Thursday November 24, 2011 "German Bond Sale Spurs Worries".

${ }^{50}$ Communication from the Commission to the European Parliament, the Council,, the European Economic and Social Committee, and the Committee of the Regions and the Court of Auditors, On the Commission Anti-Fraud Strategy, $\operatorname{COM}(2011) 376$ final

${ }^{51} \operatorname{COM}(2011) 376$ final at 3. Brussels, 24. 6. 2011.
} 
for investigators and prosecutors, and to possible institutional developments such as the setting up of a European Public Prosecutor's Office.

Complementing those initiatives, the Communication on Fighting Corruption in the EU15 sets an EU anti-corruption reporting mechanism for periodic assessment of Member States ('EU Anti-Corruption Report').

The Commission Work Programme for 2011 also includes a Proposal for a new legal framework on the confiscation and recovery of criminal assets under the heading 'Initiatives on Protecting the Licit Economy'.

After all this well-intended language, the final guiding principles for action are once again watered down when dealing with criminal law. In addition to reinforcing areas of ethics, transparency, fraud detection and cooperation between Member States i. e. business as usual, the Commission considered that in the field of EU sanctions for misconduct affecting EU funds:

Justice must be achieved with due process and in reasonable time. Procedures must provide for enhanced standards of due process using mechanisms that enable swift and independent action. In addition to adequate sanctions, convicted and administratively sanctioned persons must be effectively deprived of the proceeds of their offence and defrauded resources must be recovered.

In developing the sanctions it will use, the Commission only considers "financial and/or administrative penalties" $" 52$. The question is then: What happened to criminal sanctions? ${ }^{53}$

\section{Towards a EU criminal policy}

The response is to be found in a recent communication of the EU Commission dated September 29th, 2011 in which, again, the Commission addresses other EU institutions. The title of the communication sounds promising: "Towards an EU Criminal Policy: Ensuring the effective implementation of EU policies through criminal law" ${ }^{\prime 2}$. The problem actually might be the sweeping breadth of its objective: from the narrow scope of EU financial interests that is of absolute concern nowadays, to the broad approach of implementation of EU policies through criminal law. The Commission lost its focus and in doing so, it also lost the persuasive nature of the arguments in favor of a strong EU criminal law in a narrowly tailored area such as the protection of the financial interests of the EU.

\footnotetext{
$52 \operatorname{COM}(2011) 376$ final at 15.

53 The short answer is that the Commission has no authority to impose such sanctions. The longer answer is that the most powerful EU institution, the EU commission, is still reluctant to test the waters of criminal sanctions. Without doubt, as an administrative authority, it will never have the necessary power to use criminal sanctions. But most certainly, it can definitely focus its actions in enforcing that criminal courts across the EU impose those sanctions based on European Rules of Criminal Procedure and pursuant to the charges filed by European Prosecutors. These features will be explored in greater detail below, but the point to make at this stage is that clearly, the EU Commission is not making full use, even in its communication strategy, of the deterrence effect associated with its communications.

${ }^{54}$ Communication from the Commission to the European Parliament, the Council, The European Economic and Social Committee and the Committee of the Regions. Towards an EU Criminal Policy: Ensuring the effective implementation of EU policies through criminal law. COM(2011) 573 final. Brussels, 20. 9. 2011.
} 
Wishful policies and rationales are outlined in the communication when detailing the arguments on why the EU should act in the area of criminal law ${ }^{55}$.

EU criminal law fosters the confidence of citizens in using their right to free movement and to buy goods or services from providers from other Member States through a more effective fight against crime and the adoption of minimum standards for procedural rights in criminal proceedings as well as for victims of crime.

Today, many serious crimes, including violations of harmonized EU legislation, occur across borders. There is thus an incentive and possibility for criminals to choose the Member State with the most lenient sanctioning system in certain crime areas unless a degree of approximation of the national laws prevents the existence of such "safe havens".

Common rules strengthen mutual trust among the judiciaries and law enforcement authorities of the Member States. This facilitates the mutual recognition of judicial measures as national authorities feel more comfortable recognizing decisions taken in another Member State if the definitions of the underlying criminal offences are compatible and there is a minimum approximation of sanction level. Common rules also facilitate cooperation with regard to the use of special investigative measures in cross-border cases.

EU criminal law helps to prevent and sanction serious offences against EU law in important policy areas, such as the protection of the environment or illegal employment.

It is clear from the language used that protection of EU financial interests is not the driving force behind this communication. Actually, reference is constantly made to the legal basis provided by Article 83 TFEU, which focuses on serious crossborder criminality and little attention is paid to Article 325 TFEU, which deals with the protection of EU financial interests. In short, the EU approach to the protection through criminal law of the EU budget and taxpayers' money seems to be included as one of the elements of its overall take on criminal law despite specific language in the TFEU targeting financial crimes.

\section{Will this well-intended language suffice?}

This is clearly not what the current situation demands. A strong message of vigorous supervision including criminal sanctions imposed at the EU level is necessary not only to appease the markets, but to provide deserved reassurance to EU citizens that the strain that they will be subject to is worth it. Why should some EU citizens' sacrifice enable other EU citizens to waste their money? Would it not be more reasonable and fair for the EU to closely supervise the funds raised to ensure that they are spent correctly and that any type of misappropriation is heavily punished? Indeed, EU citizens cannot trust the existing mechanisms because this is what got us here in the first place.

\footnotetext{
${ }^{55} \operatorname{COM}(2011) 573$ final at 5.
} 
Luckily this is nothing new to federal systems. The need for federal enforcement of this type of misappropriation or mismanagement of federal funds by local officials is a common theme in federal systems. And it is precisely the independent enforcement by federal (external) agencies that provide equilibrium. If the EU continues to leave the supervision and enforcement of EU funds up to the states, the result will be the same as before. The possibilities of prosecuting locally the mismanagement of $\mathrm{EU}$ funds are low, tending to be non-existent ${ }^{56}$. What is the incentive for local enforcement officials to prosecute and the local courts to convict prominent public officials for mismanaging "foreign" funds? A sense of responsibility is surely present in many members of the enforcement community. But to trust that sense as the only resource of adequate spending is plain wishful thinking. Again, the best evidence of the need for change is that the existing mechanisms have not provided adequate protection in the past. Why would they in the future? They will not.

These and other rationales are behind the federal supervision of proper spending of the TARP funds. Officials who misspent federal funds to the point of technically bankrupting an entity cannot be trusted; especially if no investigation, prosecution and conviction by the local authorities followed. Many times these local authorities request that the federal enforcement officials intervene, as they are perfectly aware of their limited power to adequately investigate, prosecute and get convictions for these crimes. To be sure, the local authorities have the man-power to conduct the investigations. But in many occasions they lack either the knowledge or the necessary authorization to proceed forward with these cases. In recognition of these deficiencies, the U. S. government created the Office of the Special Inspector General for the Troubled Asset Relief Program (SIGTARP), an office specifically charged with monitoring TARP funds. SIGTARP is only a temporary government agency meant to supplement the work done by the Treasury Department and the Justice Department. The high level of supervision of federal funds in the U.S. should serve as an indication to the EU of the level of financial oversight which is needed.

At the EU level, a similar deficiency is evident in the findings of the EU AntiFraud office, the OLAF ${ }^{57}$. In the report for the FY 2010, they consistently report the number of investigations referred to the local authorities that resulted in non prosecution. ${ }^{58}$ The figures presented of $68 \mathrm{M}$ euros recovered is dwarfed by the

${ }^{56}$ This tension between Member States and the EU will be crucial in defining the relationship between the EPPO and Member States. For a discussion of this relationship and three possible models, see Andre Klip, European Criminal Law: An Integrative Approach. 2nd Ed. (2012) at 459-464.

${ }^{57}$ The role of OLAF in the EPPO would likely be quite significant. "Currently OLAF has the expertise and the know-how as regards the investigation of offences against Union's financial interest. It is not conceivable that any future perspective in this field could be without bringing them on board, and the Action Plan for the Stockholm Programme acknowledges this." Jorge ÁngelEspina Ramos, Towards a European Public Prosecutor's Office: the Long and Winding Road in Substantive Criminal Law of the European Union (Andre Klip ed., 2011).

${ }^{58}$ For illustrative purposes, in Spain, between 1999 and 2007, OLAF sent 79 cases to Spanish prosecutors, 28 of which were decided on the merits. 11 of 28 were handled by the Special Anticorruption Prosecutor's Office, of which 3 resulted in convictions. The other 17 were territorial prosecutions, and resulted in only one conviction. "Two conclusions can be extracted from these figures: a) specialisation is a clear added value that increases the efficiency, and b) the overall figures of convictions are quite low and there is, therefore, ground for improvement." Jorge ÁngelEspina Ramos, Towards a European Public Prosecutor's Office: the Long and Winding Road in Substantive Criminal Law of the European Union (Andre Klip ed., 2011). 
fraud that is detected. This discrepancy was verified by OLAF's FY 2011 report, which stated that 691.4 M euros had been recovered. OLAF itself discounted the figure as an anomaly, citing an investigation in Italy's Calabria region that resulted in the recovery of $389 \mathrm{M}$ Euros. But even discounting the amount from that single investigation, 2011 still saw an increase of over $400 \%$ in recovered fraudulent funds. OLAF also cited a change in the form in which recovered funds are calculated as a reason for the shocking difference, but as the new reporting system will not be used until FY 2012, 2010 and 2011's figures were calculated using the same metrics. In their FY 2011 report, it states "OLAF's experience, underpinned by statistical and analytical evidence, shows that there is insufficient deterrence concerning criminal misuse of the EU budget...Additionally, practitioners have pointed out that mutual legal assistance has its limits, that the use of evidence in cross-border cases is sometimes problematic and that there is a tendency to limit prosecutions to domestic cases and disregard the European dimension". 59 . In so many words, OLAF has succinctly made the case for greater oversight of EU funds.

\section{The first benchmark: Market manipulation and LIBOR fixing}

A quick review of the development history of EU criminal law shows that the pendulum of criminal enforcement has oscillated from the protection of the EU financial interests in the late nineties to the fights against transnational criminality in the early 21st Century ${ }^{60}$; and it is back now to address concerns of white collar criminality related to the European financial markets. Without doubt, this by no means can be interpreted as a lack of attention towards the transnational dimension, but the sovereign debt crisis and its threat to the Eurozone has shown the need for real criminal law enforcement in the financial markets area. And this time, it should be clear to the EU institutions that merely referring the issue to the national authorities of the Member States is not enough, precisely because this lack of supervision from the EU created the problem in the first place. The EU reveals itself as a lame duck trying to achieve the status of a real watchdog. Yet, if the EU continues to lack criminal enforcement capacity, it will ultimately be a toothless watchdog.

It is worth noting that the first proposal for a Directive in criminal matters pursuant to the new powers embedded in the Lisbon Treaty has been on criminal sanctions for insider dealing and market manipulation ${ }^{61}$. The importance of this first step should be stressed. For the first decade of the 21st Century, the EU institutions were very much concerned with fighting drug trafficking, human trafficking, money laundering etc. But with the entry into force of the Lisbon Treaty, these important issues have been put aside and the attention focused on the

\footnotetext{
59 At 35.

${ }^{60}$ For an overview of these developments see generally the contributions in Substantive Criminal Law of the European Union (Andre Klip ed., 2011).

${ }^{61} \operatorname{COM}(2011) 654$ final.
} 
protection against certain forms of criminality aimed at the heart of the financial markets. This shift clearly shows that the main concern nowadays revolves around the idea of how to protect the European financial markets from offenses that may ultimately destabilize the economy of Member States and threat the existence of the Eurozone.

A thorough reading of the referred proposal clearly links (criminal) protection of European financial markets with the economic growth yearned for. In this sense, it will be stated later on the paper that there is an intrinsic connection between real law enforcement (including criminal enforcement) and investors' confidence. The actual words of the proposal ${ }^{62}$ are the following:

"An integrated and efficient financial market requires market integrity. The smooth functioning of securities markets and public confidence in markets are prerequisites for economic growth and wealth. Market abuse harms the integrity of financial markets and public confidence in securities and derivatives".

This consideration is a result of the impact assessments conducted by the Commission, an institution that clearly concluded that such legislation "will have a positive impact on investors' confidence and will further contribute to the financial stability of financial markets". This dovetails with the previous JHA Council conclusions on economic crisis prevention and support for economic activity, in which it was stressed that consideration could be given to whether it is possible or, as the case may be, appropriate to harmonise criminal laws regarding the handling of serious stock market price manipulations and other misconduct relating to securities markets ${ }^{63}$. As the proposal itself pointed out, the differences in Member State criminal laws on insider trading are notably divergent, and create opportunities for individuals to exploit the common European market without fear of criminal prosecution.

The recent LIBOR scandals have, if anything, stressed the importance of a centralized system of enforcement - and we may add: criminal law enforcement -. The EU has come to realize that an important part of its weakness comes from abuses by financial institutions of its own Member States. And the timid reaction of national law enforcement has proven to be insufficient. As Viviane Reding keenly worded it: "This will end the often too 'cosy' relationship that exists today between national supervisors and banks in their home country" 64 . Paraphrasing Mrs. Reding's statement: A centralized system of criminal law enforcement in this area will end the often too "cosy" relationship that exists today between national criminal law enforcement authorities and Banks (among others) in their home country.

The reaction of the EU was an amended proposal for a Directive on criminal sanctions for insider dealing and market manipulation (submitted in accordance with Article 293(2) TFEU). ${ }^{65}$ The amended proposal modified its original articles to include benchmark manipulation as a suggested criminal offense in Member States.

\footnotetext{
62 2011/0297 (COD).

${ }^{63}$ See Docc. $8920 / 10$ of 22. 4. 2010 and $7881 / 10$ of 29. 3. 2010.

${ }^{64}$ Viviane Reding, Amended Proposal for a Directive on Criminal Sanctions for Insider Dealing and Market Manipulation, Joint press conference with Commissioner Barnier/Brussels, 25 July 2012, SPEECH/12/569, at 3.

65 2011/0297 (COD).
} 
The need for these amendments demonstrates the ability of financial crimes to rapidly re-manifest themselves in new forms. Perhaps unsurprisingly then, the biggest problem (and probably paradoxically the solution) is time. Financial markets do not abide by political timing. The need to act is peremptory and a delay of months (even years) could result in an all too slow reaction. Prompt response to immediate threats has proven itself as the only way to appease the markets and provide the necessary comfort to investors seeking safe harbours to allocate resources.

V. The Second Benchmark: The Proposal for a Directive to protect European financial interest through criminal law

Shortly after the Proposal for a Directive on Insider Dealing and Market Manipulation was issued, the Parliament and the Counsel proposed a Directive on the fight against fraud to the Union's financial interests by means of criminal law ${ }^{66}$, based on Article 325 TFEU $^{67}$. Both EU institutions recognized that fraud and related illegal activities affecting the Union's financial interests pose a serious problem to the detriment of the Union budget and thereby of taxpayers. They quickly acknowledged that the Union needs to defend taxpayers' money in the most efficient way, making use of all possibilities offered by the Treaty on the European Union. The fact that Member States have adopted diverging rules and consequently often diverging levels of protection within their national legal systems has triggered action by the EU itself. In the opinion of these two important bodies of the EU, "Equivalent protection of its financial interests is also a matter of credibility of the Union's institutions, bodies, offices and agencies, and of ensuring a legitimate budget execution" $"$.

Yet, this long deserved (and sought after) equivalent protection of EU financial interests is allegedly achieved by means of a Directive. Surely, Article 325 does not call for a Directive, but leaves open to the EU the instruments to ensure an effective and equivalent protection of EU financial interests 69 . The wording reads "The European Parliament and the Council, acting in accordance with the ordinary legislative procedure, after consulting the Court of Auditors, shall adopt the necessary measures in the fields of the prevention and fight against fraud affecting the financial interests of the Union with a view to affording effective and equivalent protection in the Member States and in all the Union's institutions, bodies, offices and agencies".

The proposal then contains an array of criminal provisions that should be harmonized i. e., standardized throughout the EU. This law-in-the-books perspec-

\footnotetext{
${ }^{66} \operatorname{COM}(2012) 363 / 2$.

${ }^{67}$ To be sure, there was a heated discussion for years concerning the wording of former Article 280 (4) of the TEU - predecessor to Article 325 TFEU -. Though there were divergent interpretations of what this paragraph meant, the truth is that the current view held by the EU institution is that "Article 325 therefore includes the power to enact criminal law provisions in the context of the protection of the Union's financial interests against all angles of illegal attacks, which was not the case in the corresponding Article 280 (4) in the EC-Treaty" (COM(2012) $363 / 2$ at 7$)$.

${ }^{68} \operatorname{COM}(2012) 363 / 2$, at 4 .

${ }^{69}$ For a discussion on Article 325 TFEU and its significance, see Rosaria Sicurella, Some reflections on the need for a general theory of the competence of the European Union in criminal law, Substantive Criminal Law of the European Union (Andre Klip ed., 2011).
} 
tive is certainly welcomed, but it will surely fall short in securing adequate enforcement. A greater emphasis in the law-in-action perspective is needed if EU institutions are willing to provide legitimate protection to EU taxpayers' and investors' money. Notwithstanding the unbalanced protection of EU financial interests by the penal codes of EU countries, the enforcement action taken by such countries has been even less reassuring. In other words, the real problem is located at the criminal enforcement of such provisions.

\section{The third benchmark: The European Prosecutor Office}

Substantive criminal law has been the main field of discussion so far. The most obvious impact of EU criminal law, however, pertains to the realm of procedural law. The number of EU legislative instruments that model the contours of national procedural legislation is ever increasing. From the EAW to the EEW, from Art. 54 CAAS to the Directive of Conflicts of Jurisdiction, the everyday impact of these and many other framework decisions and directives can be clearly observed from a practitioner's point of view. However, substantive regulation without an adequate procedure is doomed to failure. Therefore, it is easily comprehensible that the above related proposals should be complemented by measures in the procedural field to respond to the deficiencies they identified in this context ${ }^{70}$.

Not surprisingly the possibility of creation a European Public Prosecutor Office [EPPO] has been heavily discussed ${ }^{71}$ The Corpus Iuris already contained certain provisions regulating this proposed institution, although the breadth of the proposal might have been a bit premature for the then political willingness ${ }^{72}$. . Shortly after, a Green Book linking the protection of the EU financial interests to the establishment of the European Prosecutor was produced ${ }^{73}$. Yet, the actual legislative proposal at the time left out of the picture the latter, and concentrated on the former ${ }^{74}$. In any event, it never was enacted. A few years later, the first drafts of the "Constitution for Europe" foresaw a European prosecutor with jurisdiction in cases involving not only EU financial interests, but all sort of serious cross-border criminality. The final text confined the EPPO to the protection of EU financial interests ${ }^{75}$. and the current Lisbon Treaty has maintained this approach in article $86^{76}$.

\footnotetext{
70 "A central theme of the different models suggested for the creation of the EPPO is to define in how far it is necessary to adopt a harmonised set of procedural rules for the functioning of the supranational EPPO, and to which extent it is possible to rely on mutual recognition." These procedural measures would have to take into account the need for harmonisation, as well as mutual recognition. See KatalinLigeti, The European Public Prosecutor's Office: Which Model?, Substantive Criminal Law of the European Union (Andre Klip ed., 2011).

$71{ }^{1}$ See Valsamis Mitsilegas, EU Criminal Law, 2009, at 229 noting that it has been one of the most controversial issues in the development of EU criminal law.

$72 \mathrm{http}$ ///ec.europa.eu/anti_fraud/documents/fwk-green-paper-corpus/corpus_juris_en.pdf.

${ }^{73} \operatorname{COM}(2001) 715$ final.

${ }^{74} \operatorname{COM}(2001) 272$ final.

${ }^{75}$ Article III-274. CIG 87/1/04.

${ }^{76}$ For a comparison of two other proposed procedural frameworks for the EPPO, the Corpus Juris and the Green paper, see Katalin Ligeti, The European Public Prosecutor's Office: Which Model?, Substantive Criminal Law of the European Union (Andre Klip ed., 2011).
} 
Times have changed. And, as it is contended in this essay, the need for real law enforcement action by the EU has become extremely palatable. Recently, the EU Commission proposed a Regulation establishing the European Public Prosecutor Office $^{77}$. Needless to say, this is a qualitative leap as it creates a supranational authority in criminal law with jurisdiction over the EU territory ${ }^{78}$. This initiative is inexorably linked to the proposed Directive on the protection of EU financial interests through criminal law $^{79}$, i.e., the EPPO will have jurisdiction over the crimes contained in the directive. Precisely because this is proposed legislation, it is worth mentioning certain issues that should be amended to avoid problems that are fairly well-known in federal systems.

First, it should always be stressed the federal nature at the core of this institution. As Commissioner Reading adequately worded this idea in her speech presenting the Regulation establishing the EPPO: "A federal budget needs federal protection". This implies that national interests cannot continue to play a decisive role in these matters. The emergence of a truly European federal interest should be clearly acknowledged to avoid watering down an institution that must have the necessary teeth to fulfill its primal function.

Second, using a Regulation - specifically prescribed in article 86 TFEU - is aimed at ensuring unified enforcement throughout the EU. The advantages that this type of legal instrument offers should not be wasted. Although the relationship with Eurojust and OLAF should be clarified to a greater extent ${ }^{80}$ the opportunity to implement the full mandate contained in article 86 TFUE should be seized, specially regarding the evidence law as it will be noted below.

Third, the decentralized model that the EU Commission has chosen comports coordination difficulties $^{81}$. Although European Delegated prosecutors must comply with the guidelines issued by the European Public Prosecutor, the "double hat" structure will imply sooner than later conflicts between the orders of the European Public Prosecutor and of the National Attorney General. The fact that Member States remain secondary civilly liable in case of conviction poses a clear conflict of interests that already accounts for the current lack of enforcement of national provisions protecting EU financial interests. A centralized model with sufficient Deputies of the EPPO is preferable from a technical point of view. The long-term price of EPPO independence outweighs the short-term price of setting up the structure ${ }^{82}$.

\footnotetext{
77 COM(2013)534final.

${ }^{78}$ See already J.A.E. Vervaele, Quel statut pour le ministère public?, Quelles perspectives pour un ministère public européen? Protéger les intérêts financiers et fondamentaux de l'Union 189 (2010).

${ }^{79} \operatorname{COM}(2012) 363$ final.

${ }^{80}$ See Jorge Ángel Espina Ramos, Towards a European Public Prosecutor's Office: the Long and Winding Road, Substantive Criminal Law of the European Union 35 (Andre Klip ed., 2011). Already noting the need Annika Suominen, The Past, Present and the Future of Eurojust, 15 Maastricht Journal of European and Comparative Law 229 (2008). On the new role of OLAF see Valentina Covolo, From Europol to Eurojust - Towards a European Public Prosecutor. Where Does OLAF Fit In?", Eucrim 2/2012, at 83.

${ }^{81}$ Also, the lack of democratic control over the EPPO has already been voiced by Martin Zwiers, The European Public Prosecutor's Office (2011) at 373

${ }^{82}$ Budgetary concerns in the era of austerity are outright legitimate. The possibility of using national prosecution services and therefore minoring the budget that will be needed to establish the EPPO is clearly tempting [see also
} 
Fourth, there is a clear risk of forum shopping. Many academics have previously warned against this risk ${ }^{83}$. The EPPO could decide to bring its case in front of the most favourable jurisdiction to its interests. Not only because the Directive governing the crimes over which the EPPO has jurisdiction might be implemented different across the EU, but because the lack of standardized provisions concerning evidence law in the EU Regulation establishing the EPPO will certainly create various regimes inside the EU. In short, the EPPO will be able to maneuver accordingly attracting jurisdiction to the countries it perceives more friendly to its interests.

Fifth, the Directive that establishes the crimes over which the EPPO has jurisdiction expands the traditional notion of EU fraud crimes in the Member States. Under the title of "Fraud related criminal offenses affecting the Unión's financial interests", the Directive contains in article 4 public corruption (active and passive) and misappropriation offenses. This will imply that national public officials that deal with the EU funds will be prosecuted (in such cases) will be theoretically prosecuted by supranational authorities, although the delegated representatives of such authority will be local. Needless to say, the conflict of interest is well served.

Sixth, a major deficit in the current proposal has to do with judicial review ${ }^{84}$, a key feature in every system of criminal justice. As of today, judicial review will be granted before the judicial national authorities, with a generic warning concerning the need (and actual obligation) to request prejudicial rulings from the ECJ pursuant to article 267 TFEU. The theory is clear: whenever there is no further appeal against a decision from the national courts, then a prejudicial ruling from the $\mathrm{ECH}$ should be granted. But as practitioners around the EU are very well aware of, national courts in many member states are reluctant to file such requests. Some academics $^{85}$ proposed a special chamber for criminal matters within the ECJ on the basis of article 257 TFEU to deal with judicial review of EPPO decisions. This would provide a much more adequate relief for defendants across EU territory and would ensure a uniform interpretation of the boundaries of EPPO action ${ }^{86}$.

Seventh, and probably the most pressing issue, the Commission's proposal did not seize the opportunity to establish a thoughtful and consistent body of evidence law governing EPPO action ${ }^{87}$. In article 30 of the proposal, admissibility of evidence

Simone White \& Nicholas Dorn, Towards a Decentralized European Public Prosecutor's Office?, 89 Amicus Curiae 7 (2012)]. Also, linguistic diversity throughout the EU might play a significant role in the option chosen by the EU Commission. However, both of this issues dwarf in comparison with the possibility of establishing a centralized enforcement authority that only serves the interests of the EU.

${ }^{83}$ Jorge Ángel Espina Ramos, Towards a European Public Prosecutor's Office: the Long and Winding Road, Substantive Criminal Law of the European Union 35 (Andre Klip ed., 2011). The report that was produced pursuant to the Green Book also reflected this deficit. [COM(2003) 128 final].

${ }^{84}$ Jorge Ángel Espina Ramos, Towards a European Public Prosecutor's Office: the Long and Winding Road, Substantive Criminal Law of the European Union 35 (Andre Klip ed., 2011) at 43.

${ }^{85}$ See Carlos Gómez-Jara Díez, Models for a System of European Criminal Law: Unification vs. Harmonization, 1 New Journal of European Criminal Law 398 (2010). See also http://www.eppo-project.eu/.

${ }^{86}$ At least, the proposed legislation should make good use of the possibility provided by article 86 TFEU to introduce the "rules applicable to the judicial review of procedural measures taken by it in the performance of its functions" and establish the standards governing judicial review.

${ }^{87}$ Some had already noted the need and convenience of establishing a body of evidence law in this respect [see Carlos Gómez-Jara Díez, Models for a System of European Criminal Law: Unification vs. Harmonization, 1 New Journal of 
should be granted unless the admission would "adversely affect the fairness of the procedure or the rights of defence as enshrined in Articles 47 and 48 of the Charter of Fundamental Rights of the European Union". Though probably well intended, the provision falls short to provide an effective standard, specially if judicial review lays on the hand of national judicial authorities. It has been noted that this is an extremely controversial area of law $^{88}$ given national divergences concerning admissibility of evidence and the natural reluctance of admit evidence produce in other states. It would be wise to make good use of the possibility to determine the general rules "governing the admissibility of evidence" pursuant to article 86 TFEU and elaborate a comprehensive set of rules similar to the US Federal Rules of Evidence ${ }^{89}$.

The Commission's proposal should be more than welcome. But we should make sure it does not fall short to provide the adequate response. As the head of the EU anti-fraud office OLAF, Giovanni Kessler recently stated: "We need to have a European reaction, a European answer, and the answer is to have a European Public Prosecutor's Office in charge. This is in the European treaty, the Commission is working on it, and I hope the Parliament is also on track" 90 . The willingness of the EU Institutions, then, seems clear, especially if we take into consideration that the fight against corruption is closely related to the protection of the EU financial interests ${ }^{91}$. The final push might come from a more practical point of view: How will the markets react to a EU with (criminal) enforcement capacities. The answer, as noted below, fits perfectly into the arguments raised so far.

\section{Law enforcement and investors rationality: Some lessons from the law \& finance debate}

For years, the prestigious Law \& Finance school of thought has studied the relationship between legal regulation of financial markets and the reaction it triggers in investors around the world ${ }^{92}$. Using a sample of some forty-nine countries, they found a statistically significant relationship between the origins of a country's laws and its level of financial development ${ }^{93}$. According to their findings, common law

\footnotetext{
European Criminal Law 398 (2010); Helmut Satzger, International and European Criminal Law 116 (2012)]. Others have considered the possibility of entrusting the principle of mutual recognition with the task of providing an adequate solution to the evidence problem [Katalin Ligeti, The European Public Prosecutor's Office: Which Model?, Substantive Criminal Law of the European Union (Andre Klip ed., 2011) at 61], though finally conclude that it is unrealistic to believe it will be up to the task.

${ }^{88}$ See Katalin Ligeti / Michele Simonato, The European Public Prosecutor's Office: Towards a Truly European Prosecution Service?, 4 New Journal of European Criminal Law Review 19 (2013).

${ }^{89}$ See Henning Radtke, The Proposal to Establish a European Prosecutor, Harmonization of Criminal Law in Europe (Husabo / Strandbakken eds., 2005) at 113, who was extremely reluctant to the institution of a EPPO if it was not accompanied by a set of criminal procedure rules.

${ }^{90}$ Available at: http://www.euractiv.com/justice/olaf-chief-pleads-european-publi-news-516487

${ }^{91}$ If theUnion is unable to address the issue of corruption properly and in an efficient way "the EuropeanUnion as such is at stake", he pleaded [Available at: http://www.euractiv.com/justice/olaf-chief-pleads-european-publi-news516487].

92 See among many Rafael La Porta, Florencio Lopez-de-Silanes, Andrei Shleifer, and Robert W. Vishny, Law and Finance, 106 J. Pol. Econ. 1113 (1998).

${ }^{93}$ La Porta et al., 106 J. Pol. Econ. 1113 (1998), at 1151
} 
origin countries had grown at a faster rate $(4.3 \%$ per capita) than French civil law origin countries (3.2\% per capita). ${ }^{94}$ As they noted "the evidence on the importance of the historically determined legal origin in shaping investor rights ... suggests at least tentatively that many rules need to be changed simultaneously to bring a country with poor investor protection up to best practice." 95

These studies focused heavily in the law on the books and established that adequate regulations protecting investors' rights furthers a more rapid and solid development of such markets. This would suggest that if the EU institutions are to provide the adequate regulatory framework, market credibility could be restored rapidly". However, recent studies have shown that the "law on the books" approach fails to factor adequately the most decisive factors in the development of a sound market place of securities and sovereign debt: the enforcement side.

As Columbia University Law School Professor Coffee points out ${ }^{97}$, what really seems to be the decision-making factor is the degree of enforcement of such regulation in a specific jurisdiction ${ }^{98}$. In this sense, if the EU insists on providing adequate regulation whose enforcement is left thereinafter to the national authorities of the Member States, the signal will err at its aim. The enactment of the proposed directives without the simultaneous creation of an EPPO will fall short of providing investors with the much needed relief that if something goes awry with the financial institutions in the EU, the EU will step in and prosecute the persons responsible for such misconduct.

A clear example of what we just said is the intense litigation in the USA regarding foreign-cubed securities ${ }^{99}$. Why do investors around the world flock to the US system of federal law to file their claims for misrepresentation and other fraud related issues pursuant to Section 11 of the Exchange Act of 1933 and Rule 10b-5? The answer is quite simple. Given the level of enforcement, this system provides the necessary warranties such that investors feel safe in the sense that any type of misconduct will be subject to real enforcement. To be clear, the US system has been a victim of its own success and major litigation in this field for years has resulted in a

\footnotetext{
${ }^{94}$ La Porta et al., 106 J. Pol. Econ. 1113 (1998).at 1138 tbl.II.

95 Rafael La Porta et al., Investor Protection and Corporate Governance, 58 J. Fin. Econ.3, 20 (2000).

${ }^{96}$ Howell E. Jackson, Regulatory Intensity in the Regulation of Capital Markets: A Preliminary Comparison of Canadian and U.S. Approaches, in The Task Force To Modernize Securities Legislation in Canada, Canada Steps Up: Research Studies: Strengthening Market Credibility and Integrity 75, 98 (2006), available at http://www.tfmsl. ca/docs/V6(2)\%20Jackson.pdf.

${ }^{97}$ John C. Coffee, Law and The Market: The Impact of Enforcement, 156 U. Pa. L. Rev. 229 (2007). The basic tenet of Coffee's article is to suggest that only one legal variable-the level of enforcement intensity-distinguishes jurisdictions in a manner that can explain national differences in the cost of capital and therefore determine the decision-making process of investors. See also John C. Coffee, Jr., The Rise of Dispersed Ownership: The Roles of Law and the State in the Separation of Ownership and Control, 111 Yale L. J. 1, 8-9 (2001) (arguing that the level of state control over the economy, rather than the nature of a country's legal system, most influences its financial development).

${ }_{98}$ The literature on securities regulation has long underplayed this public-regarding role, but non investors as well as investors depend on the efficiency of securities regulation, as the costs of underenforcement fall on the economy as a whole.

${ }^{99}$ See the explanation of this type of litigation provided in Stephen J. Choi\& Linda J. Silberman, Transnational Litigation and Global Securities Class Actions, 2009 WIS. L. REV. 465, 476 (2009).
} 
recent setback by the US Supreme Court reducing the availability of US enforcement to foreign investors ${ }^{100}$.

Precisely the fact that empirically foreign investors are attracted to the legal system that provides the highest standards of enforcement should serve as a guiding factor for the difficult decision that lay before EU institutions. If the EU is able to provide a uniform system of enforcement at the EU level (not national level) in matters concerning criminal misconduct affecting EU financial interests, investors will surely regain confidence lost in the sovereign debt issued by EU Member States as they will feel that no excess will go unpunished ${ }^{101}$. They will be confident that no connivance between national authorities and national banks will take place ${ }^{102}$. Begging the question is just extending the agony.

\section{Conclusion}

At a critical time in which the future of the EU itself is at stake, a narrow timeframe has opened up to provide EU financial interests with the necessary protection for the future. If the dramatic events of the European sovereign debt crisis are to be averted, an EU centralized criminal protection has to be institutionalized. This shall include EU provisions and EU enforcement. In short: a "federalized" protection. The ever recurring objection of sovereignty withdrawal away from the Member States can be easily addressed in modern circumstances. If EU countries are transferring sovereignty in critical decisions affecting the core of national political will, enabling the EU to protect its own financial interests seems to be a rather small concession.

Legitimate concerns of investors and EU taxpayers alike are fundamentally aligned with EU sovereignty. Investors will feel that their investments are safer; EU taxpayers will sense greater accountability; and the EU will finally be able to protect

${ }^{100}$ See John C. Coffee, Extraterritoriality After Morrison: Gray Areas Remain, New York Law Journal, 2012. As Professor Coffee lays out, the goals in Morrison v. National Australia Bank, 130 S. Ct. 2869 (2010) were both (1) to reduce legal uncertainty (because the Second Circuit's prior "conduct" and "effect" tests had proven murky), and (2) to minimize U.S. interference with the regulatory affairs of other countries (in part because the extraterritorial application of Rule 10b-5 could threaten the solvency of foreign corporations that had no more than a legal toe in U.S. waters).

101 As the referred Proposal for a Directive on criminal sanctions for insider dealing and market manipulation (2011/0297 (COD)) points out: "An integrated and efficient financial market requires market integrity. The smooth functioning of securities markets and public confidence in markets are prerequisites for economic growth and wealth. Market abuse harms the integrity of financial markets and public confidence in securities and derivatives". This consideration is a result of the impact assessments conducted by the Commission that clearly conclude that the legislation "will have a positive impact on investors' confidence and will further contribute to the financial stability of financial markets". This dovetails the previous JHA Council conclusions on economic crisis prevention and support for economic activity, in which it was stressed that consideration could be given to whether it is possible or, as the case may be, appropriate to harmonise criminal laws regarding the handling of serious stock market price manipulations and other misconduct relating to securities markets. See Docc. 8920/10 of 22. 4. 2010 and 7881/10 of 29. 3. 2010 .

102 The connection between both has been obvious [see generally Arturo Estrella and Sebastian Schich, Sovereign and banking debt interconnections through guarantees, OECD Journal: Financial Market Trends, Volume 2011, at 21]; especially in countries like Spain where national Banks purchase the highest percentage of Spanish sovereign debt. This causes a natural tendency for the government to relax standards for banks. 
its own financial interest without having to trust national enforcement authorities. This movement should reassure financial markets of the EU's determination to restore market confidence for the long term. From this perspective, it seems to be a win-win solution. 